\title{
A RICH VEIN? NOVEL DISSEISIN AND THE TROWELL COALMINE CASE OF 1258
}

The Trowell mine case was a dispute over a property holding and the right of common of pasture that was brought to court under the assize of novel disseisin, and heard before the recently appointed Justiciar, Hugh Bigod, and Gilbert of Preston at the Nottingham assizes on 4 September 1258, probably in Nottingham castle. ${ }^{1}$ Novel disseisin occupies a central role in the evolution of English common law. ${ }^{2}$ In many ways this case is typical of the assize, in itself significant for its widespread usage by people of all stations and the implications that this suggests about their perception of the crown. Its greater value however lies in its ability to unravel, and add considerable detail to our understanding of, four crucial themes: the maintenance of justice in a period of political disruption; the varied employment of woodpasture and enclosed land in the thirteenth century; the earliest evidence for coal mining in Nottinghamshire; and a particularly rare glimpse of how mined coal was sold at the pit head. Pleas of novel disseisin, and indeed other categories of civil pleas, have much to contribute to the study of social history, particularly of the late twelfth and thirteenth centuries when other sources are less abundant. Part I of this article discusses the assize of novel disseisin, Hugh Bigod's role as Justiciar and examines the details of the case from a legal and tenurial perspective; Part II examines what the case reveals about wood-pasture and enclosure in the early thirteenth century; and Part IV investigates what the case tells us about early coal mining in Nottinghamshire in general and pit-head sales in particular.

\footnotetext{
${ }^{1} \mathrm{~T}$ [he] N[ational] A[rchives], P[ublic] R[ecord] O[ffice], JUST 1/1187, rot. 17.

${ }^{2}$ Henry de Bracton, De Legibus et Consuetudinibus Anglice, ed. G.E. Woodbine, trans. with revisions and notes S.E. Thorne (4 vols., Cambridge, MA, 1968-77), iii. 18-204; J.H. Baker, An Introduction to English Legal History (4th edn., London, 2002), pp. 233-4, 236, 422-4; S.F.C. Milsom, A Natural History of the Common Law (New York, 2003), pp. 87-92, 104-6; F. Pollock and F.W. Maitland, The History of the English Law before the Time of Edward I, I: Sketch of Early English Legal History (2nd edn., Cambridge, 1911), pp. 145-6; D.W. Sutherland, The Assize of Novel Disseisin (Oxford, 1973).
} 
The twelfth and thirteenth centuries witnessed the frequent ejection of freeholders from their property without a legal judgement. This presented a continual problem to the crown, concerned to uphold lawful possession, which found a means of redress in the assize of novel disseisin. $^{3}$ Issued in 1166 with only two criteria, that the plaintiff must be free and the action brought within a specified time limit, it became immediately popular. ${ }^{4}$ It could be brought only before a royal court, with or without the king, at Westminster or on progress, or in the counties, where itinerant justices heard actions which were usually specific to the area. In this way the property suits of freeholders were removed from local jurisdiction and became a royal preserve, the Trowell dispute being a case in point. A suit originated with a royal writ addressed to the sheriff of the county wherein the disputed property lay. ${ }^{5}$ It initiated a defined procedure which resulted in all parties appearing before a specified court on a predetermined day and involved an inspection of the property by twelve local men who subsequently sat in court as the jury. Despite frequent references within the rolls to neighbours who defaulted in these duties, the majority appear to have been conscientious and well informed. ${ }^{6}$ The Trowell mine case is a good example of this.

Most hearings were straightforward and short. Successful plaintiffs were at once repossessed of their property, winning defendants remained in situ, and damages were often awarded. Losing principals and their supporters were amerced, that is, they fell into the mercy of the king as convicted wrong-doers and fined accordingly. The action failed if the writ were incorrect or the plaintiff absent. In the defendant's absence, the plaintiff won by default. Nonattendance was excused only for proven serious illness or if a litigant were on the king's service. Missing principals, their guarantors whether present or absent, and defaulting jurors

${ }^{3}$ R.C. van Caenegen, The Birth of the English Common Law (2nd edn., Cambridge, 1988), p. ix; Sutherland, Novel Disseisin, p. 2.

${ }^{4}$ Sutherland, Novel Disseisin, p. 1.

${ }^{5}$ For the text of a standard writ of 1188 , see ibid., pp. 14-15.

6 The Earliest Lincolnshire Assize Rolls, A.D. 1202-1209, ed. D.M. Stenton, Lincoln Record Society, xxii (1926), nos. 327, 249; The 1235 Surrey Eyre, vol. II, ed. C.A.F. Meekings and prepared for press by D. Crook, Surrey Record Society, xxxii (Guildford, 1983), no. 250; The Roll and Writ File of the Berkshire Eyre of 1248, ed. M.T. Clanchy, Selden Society, xc (1973), nos. 307, 556, 582. 
were all amerced. It was therefore in the interest of litigants to appear and argue their case. From 1227 onwards attorneys, and out-of-court agreements between litigants who were both present, were disallowed to keep the process rapid. Cases were recorded by the clerk of the court consecutively as they were heard, in identical format and in Latin, although pleas and verdicts are likely to have been voiced in dialect English. While formulaic and terse, many records still convey a sense of the atmosphere of a particular hearing.

By an unrelated accident of organisation, the date appointed for the Trowell hearing, 4 September 1258, put it into a critical period of time when the tension within law courts must have been particularly high. ${ }^{7}$ The summer and early autumn of that year fell into an intermediate period between the barons' statement of intent in the May and its execution which began the following November. The barons' Provisions of Oxford arranged, among other stipulations, for special eyres to investigate accusations of corruption and oppression in the country against central and local government. In preparation, four knights were appointed in each county to compile records of such grievances which were to be held in situ pending the arrival of the bench. They were to be heard alongside routine complaints by Hugh Bigod, whom the barons elected from among themselves at the Oxford Parliament in June and created Justiciar of England - a lapsed office since 1234-for the purpose. It seems that Bigod was expected to begin work in August but arrangements were altered so that, instead, it was on the fourth of that month that the knights were countermanded to lodge their findings at Westminster in the following October. It is possible that, had the original plan been followed, this case would have fallen within that special remit. As matters stood, it still came before Bigod who, as Hershey points out, was initially faced with the prospect of several weeks' delay_-June to August-before the commissioned knights were first to have filed their reports. ${ }^{8}$ To pre-empt accusations of inactivity and disregard for the dispensation of justice, and to prevent the King from regaining lost ground, he filled the time by taking

${ }^{7}$ The 1258-9 Special Eyre of Surrey and Kent, ed. A.H. Hershey, Surrey Record Society, xxxviii (2004), pp. xxiii-vii, xxxviii-xliii, lxv-x.

${ }^{8}$ 1258-9 Special Eyre, ed. Hershey, p. xli. 
itinerant courts around the country to hear assizes and pleas of all kinds. When the special eyres were again delayed, until October, he simply repeated the process. The Trowell case falls into this second period, before the knights finally returned their findings.

These interim eyres were not specific to counties nor were the cases organised into hundreds to synchronise with the knights' enquiries as they were for the special eyres. It is believed that Bigod was accompanying the King on a royal tour of fourteen counties, although there is only one mention of Henry being present in court, at Woodstock. ${ }^{9}$ Cases prior to October, however, include complaints of the kind which the barons were addressing, although there is no record of a special eyre as such before November and none at all for several of these counties including Nottinghamshire. On the other hand, Jacob briefly considers the possibility that the commissioned knights had already enrolled the grievances from most of the counties which Bigod visited before October and that, having the information to hand, he simply went ahead with them while he was there with the King. Otherwise, it is difficult to understand why he did not postpone them, as he may have had to do elsewhere the following year. ${ }^{10}$ The dates fit since most of Bigod's courts during the course of the summer were held after the beginning of August, the time originally appointed for the knights' returns. If this is correct, the Trowell mine case may have formed part of an eyre that was 'special' in all but name and organisation. The itinerant courts dealt with complaints of every kind in the ordinary course of justice which, according to medieval commentators, Bigod dispensed with even-handed restraint throughout his time in office although he was not a career judge and without experience of eyres. ${ }^{11}$ His election in these circumstances indicates that his peers held him in high regard and their restoration of the office of Justiciar, though only for a limited period, suggests that they believed that it enjoyed

\footnotetext{
${ }^{9}$ E.F .Jacob, Studies in the Period of Baronial Reform and Rebellion, 1258-1267 (Oxford Studies in Social and Legal History, 8; Oxford, 1925), p. 41, n.

${ }^{10}$ Ibid., pp. 42-3; see also 1258-9 Special Eyre, ed. Hershey, p. 1xv.

${ }^{11} 1258-9$ Special Eyre, ed. Hershey, pp. lxvi-lxvii.
} 
popular significance and would increase their authority. ${ }^{12}$ Bigod often sat alone, rather than with several others as previously customary, but was sometimes joined by Roger of Thurkelby or, as here, Gilbert of Preston, who were both experienced justices. It is intriguing then that this case with its attendant rights-of-common issues was heard at a time of high, possibly frustrated, expectation across the country and before the very lord whose reestablished office may have recalled a perceived golden age of justice and whose eyres must have been keenly anticipated.

The Trowell mine case comprises two complaints involving the same principal litigants. They were heard together but decided and adjudicated separately. It is likely, however, that they were closely connected and that this was the reason why they were not presented as separate suits. It first comes to notice in an entry in the fine rolls dated 24 April 1258, less than a fortnight before the Provisions were issued, when Gilbert of Brinsley offered $1 / 2$ a mark for a writ ad terminum. ${ }^{13}$ This was much more expensive than the standard writ which a plaintiff bought for about $6 d$ to bring an action before the next, routine, eyre visitation. Nevertheless it was frequently purchased by those who did not wish to wait for the next eyre, which might be months or years distant, but to have their hearing specially commissioned. ${ }^{14}$ Both types of fee were accounted for into the Exchequer. Payment for a writ ad terminum was 'entirely voluntary' since those unwilling or unable to meet it were not denied the hope of justice, only obliged to wait longer to access it, and throughout Henry III's reign there was a 'gigantic expansion' in the number of such payments. ${ }^{15}$ The granting of the

\footnotetext{
${ }^{12}$ 1258-9 Special Eyre, ed. Hershey, pp. lxv-lxvi.

${ }^{13}$ 'S. Gilbert[us] de Brimmesley' dat di[midiam] marc[am] p[ro] uno br[eve] ad t[er]m[inum] [e]t mand[atus] est vic[omiti] Notingh' [e]tc[etera] c[oram] R[ege] ap[ud] Westm[onasterium] . xxiiij die Ap[ri]l[is]': Henry III Fine Rolls Project: A Window into English History, 1216-1272, 42 Henry III (28 Oct. 1257-27 Oct. 1258), C 60/55, m. 7, http://frh3.org.uk/content/fimages/C60_55/m07.html.

${ }^{14}$ Brevia Placitata, ed. G.J. Turner and completed with additions by T.F.T. Plucknett, Selden Society, lxvi (1951), p. liii.

15 D. Carpenter, 'Introduction to Rolls', in Henry III Fine Rolls Project, http://frh3.org.uk/content/commentary/historical_intro.html, para. 1.
} 
consequent commission was generally endorsed in the patent rolls, often within two or three days, however no such commissions have been found on the relevant rolls.

Jacob also stated that the roll in which the case is recorded did not contain special commissions, yet Gilbert undoubtedly applied for one. ${ }^{16}$ The solution to this apparent mystery may lie in the rapid sequence of events. The Oxford Provisions followed hard on the heels of Gilbert's application and even while they were in preparation may have suspended the customary routine procedure. The special eyres announced by the barons removed the need for special commissions and would, in any case, have been impossible to operate if Bigod were to hear all the assizes himself, as the barons apparently intended. It may be therefore that they were disallowed during the Justiciar's term of office. If this were so, it is unlikely that Gilbert found himself out of pocket. The enrolment of his offer implies that the $1 / 2$ mark was to be collected at a future date rather than taken at the time. The Provisions also allowed for an oral complaint, the querela, to be used alongside the writ in order to reduce bureaucracy and simplify procedure. ${ }^{17}$ While the main purpose of this policy was to expedite the investigation into corruption, the barons also made the querela available to run-of-the-mill litigants. Whether or not Gilbert would have taken this course had he been aware of it is not known. As it was, he employed the standard writs of novel disseisin of a free tenement and of common.

The case came before the Justiciar and Preston, as noted above, some four-and-a-half months after Gilbert's application for a commission. Gilbert of Brinsley firstly claimed that he freely held a portion of woodland in Trowell of which he had been dispossessed by Robert of Strelley. Thoroton notes that Gilbert's family 'had their name from the place (Brinsley) very anciently'. Gilbert himself inherited the manor there with a manor in Trowell in 1228 whist he was yet under-age. He died in 1279 and in 1430 his descendants still held land in

\footnotetext{
${ }^{16}$ Jacob, Studies in the Period of Baronial Reform, p. 42.

${ }^{17}$ A.H. Hershey, 'Justice and Bureaucracy: The English Royal Writ and “1258”, ante, cxiii (1998), pp. 829-30, 851.
} 
both places. ${ }^{18}$ Robert's family had held land in Strelley since the mid-twelfth century and early in Henry III's reign also came into a manor in Trowell, Robert inheriting them in 1229. ${ }^{19}$ At the time of this dispute then, both Gilbert and Robert held manors in Trowell although the main holdings of both were elsewhere. Robert's manor must have included the wood in question since he was able to exclude Gilbert and others from entering it. He stated that he and Gilbert worked the coal together, having come to a mutually acceptable agreement. It is possible that they held the woodland jointly of a common overlord, as implied by Robert (dicit...quod revera ipse et predictus Gilbertus tenent pro indiviso predictum boscum). They appear to have initially worked together as equals, but Gilbert's lordship gave him no stronger rights in the wood than those which accrued to him as a free tenant of it. That was what he claimed to be, and no-one challenged him. Robert was well aware of the strength of Gilbert's position, for he made no attempt to question the validity of his holding. His sole argument lay in the alleged agreement between them which was that, if one of them ceased to mine the coal, the other would cease to do so also. It was through that agreement, he said, that he had prevented Gilbert from taking coal and he had dispossessed him in no other way (ipse per conventionem illam non permisit ipsum carbonem ibidem capere et nullam aliam disseisinam ei inde fecit). The implication is that he, Robert, had stopped mining the coal first, and that Gilbert had not observed the terms of their compact, thus forcing his hand.

However, Robert's motivation was more likely to have been his appreciation of the strength of Gilbert's rights in the woodland. There is no mention of these rights until the jurors gave their verdict. They said that, in preventing Gilbert from entering his wood in Trowell which was his free tenement, Robert had obstructed him from felling timber and enjoying his customary allowances there (impedivit predictum Gilbertum quod non potuit

\footnotetext{
${ }^{18}$ Robert Thoroton, The Antiquities of Nottinghamshire: Extracted out of Records, Original Evidences, Leiger Books, Other Manuscripts, and Authentic Authorities, ed. and enlarged John Throsby (3 vols., Nottingham, 1790), ii. 259-60, 199.

${ }^{19}$ Thoroton, Antiquities of Nottinghamshire, ed. Throsby, ii. 198.
} 
scindere nec aliqua estoveria capere in predicto bosco prout capere consuevit). The original writ states only that the plaintiff was dispossessed of two parts of eighteen acres of woodland with appurtenances (de duabus partibus xviij $^{\text {to }}$ acrarum bosci cum pertinenciis). The appurtenances are not specified—common practice perhaps because they were irrelevant to the case. The allowances, which were often enumerated, are here also omitted from the writ. Possibly, as they were intrinsic to the tenement and not dependent benefits, they were considered to be common knowledge. Yet the jurors expanded upon them, when they could have been content with a simple confirmation of dispossession. They specifically mentioned rights to fell timber (scindere), essential for fuel, building and maintenance, and to take other estovers (aliqua estoveria), that is, other natural resources. The jury distinguished between timber and 'other estovers', perhaps indicating that they viewed timber with its many uses as the most important woodland resource. ${ }^{20}$

Only then did they turn to the alleged agreement concerning the coalmine; not, it should be noted, the coalmine itself (dicunt etiam quod ipsi de communi assensu eorum carbonare fecerunt...absque aliqua conditione inter eos). The implication seems to be that the mine itself was regarded as one of Gilbert's estovers, a natural resource to which he was entitled as the holder of the free tenement. Robert had prevented him from using it by prohibiting Gilbert's customers from removing the coal he had sold to them (Gilbertus vendidit quibusdam carbonem...et predictus Robertus ipsos devadiavit et non permisit eos aliquid asportare de carbone predicto extra boscum). It seems that all parties were agreed on that and it was not an issue. Neither was it an issue that Robert held the same rights in the wood as his tenant. There is no sense that he should not have been involved in extracting and selling the coal quite as much as Gilbert. Rather, the case turned on whether or not there had been a valid agreement between the litigants over the way in which the mine was worked. The jury concluded precise that there had not been any such agreement (absque aliqua

\footnotetext{
${ }^{20}$ J. Birrell, 'Common Rights in the Medieval Forest: Disputes and Conflicts in the Thirteenth Century', Past and Present, no. 117 (1987), pp. 27-8.
} 
conditione inter eos provisa vel prelocuta) and that Gilbert had therefore been dispossessed of his tenement. The judges restored it to him, amerced Robert and awarded Gilbert damages of $40 s$, of which half was given to the clerks.

Gilbert claimed secondly that Robert had dispossessed him, Thomas le Rus, Henry son of Hugh and Robert of Stanley, of rights of common of pasture in Strelley and Trowell. These rights pertained to the properties which they all held in Trowell as free men, Strelley lying three kilometres to the north east of Trowell. They were probably local men and Robert, of Stanley, bears a locative surname. Stanley in Derbyshire is little more than six kilometres west of Trowell and is also on a coalfield. ${ }^{21}$ The Derbyshire settlement is one point of a regular triangle, with Brinsley and Trowell forming the other two. In 1236 Gilbert's grandfather, Robert of Brinsley, was in dispute over two bovates of land with appurtenances in Trowell with one William of Stanley, perhaps Robert's forbear. ${ }^{22}$ The record suggests a long-term connection between all three families and the locations, possibly with coal as the common denominator.

The record does not make clear whether Gilbert's tenement in this context was one and the same as his woodland tenement, in which his fellow plaintiffs were not involved. It is of note that the second claim did not relate to all of the common land in Strelley and Trowell to which the plaintiffs had right, but only to that part of it known as Le Hek. Gilbert's complaint was that, since being excluded from Le Hek, he and his fellows had less right of common there than they were used to have (minus ibidem communicare possunt sicut solebant). Defending himself against this second accusation, Robert directed his remarks to the further three plaintiffs, Thomas, Henry and Robert alone, omitting Gilbert. He claimed that the three could not have been dispossessed of rights of common of pasture in Strelley, since no common of pasture there pertained to holdings in Trowell. Further he seems to have

\footnotetext{
${ }^{21}$ Distances are approximate and as the crow flies between current settlements. There is also a village of Stanley in Nottinghamshire some 21 kilometres to the north of Trowell and again located over coal, with Brinsley lying not quite equidistantly between the two. It is about 7 kilometres south-west of Brinsley.

${ }^{22}$ Thoroton, Antiquities of Nottinghamshire, ed. Throsby, ii. 198.
} 
argued that none of the three had ever been in possession of common of pasture in those places as they claimed. Therefore, even if it did pertain to holdings in Trowell, they could not be dispossessed of it as they had never held it. He added for good measure that the disputed land was in Strelley alone and no part of it in Trowell. The jury appears to have been unimpressed, finding that Robert had dispossessed all four plaintiffs of their common of pasture in those vills which belonged to their free tenements in Trowell (Robertus disseisivit predictos Gilbertum, Thomas et alios de predicta communa pasture sue in predictis villis pertinente ad liberum tenementum ipsorum in Trowell). The judges restored possession to them, once more amerced Robert and awarded damages to the plaintiffs of $4 s$, perhaps $1 s$ each in theory, all of which went to the clerks. Robert at once requested a jury of twenty-four to overturn the verdict of the twelve. This was granted him by the judges and he paid the King, through the bench, a fine of 1 mark for it. The cost represented one-third of the damages that had been awarded against him altogether.

However, the following week at the assizes in Southwell, Nottinghamshire, again before Bigod and Preston, Robert withdrew this latest action. He had brought it against Gilbert only and had again specified le Hek. Because Robert did not press his suit, Gilbert had no case to answer but the bench found that Robert was liable for imprisonment (convincatur Gayole) and put his sureties in mercy. At the same time the judges advised him that he might have his complaint tried again (Queratur nomina [sic] plegii). No explanation is given for Robert's withdrawal but the prison sentence was presumably punishment for wasting court time by bringing the action and not proceeding with it, while the judicial advice encouraged him to resume his defence if he wished.

From the earliest extant records of the assize, there are complaints of lords preventing customary access to common land through enclosing a part of it. ${ }^{23}$ Bracton, for example,

\footnotetext{
${ }^{23}$ Earliest Lincolnshire Assize Rolls, ed. Stenton, nos. 121, 140, 413; Three Rolls of the King's Court in the
} Reign of King Richard the First, AD 1194-1195, ed. F.W. Maitland, Pipe Roll Society, xiv (1891), pp. 67, 134. 
deals at length with dispossession of rights of common of pasture. ${ }^{24}$ In 2006 , Christopher Dyer suggested that pleas of novel disseisin could generate much evidence about early enclosures. ${ }^{25}$ Our research confirms that conviction and extends that research back into the late twelfth and early thirteenth centuries. Roughly 5 per cent of a sample of 830 novel disseisin cases of the late twelfth and early thirteenth century concern enclosure of land similar to that at Trowell, suggesting that enclosure was a recognised concern at that time and that it, as Dyer suggests, occasionally precipitated violent confrontation or destruction. ${ }^{26} \mathrm{He}$ analyses twenty-one examples of enclosures which caused the most trouble, pointing out that they were largely confined, as in this case, to pastoral rather than arable areas and could involve access to woodland.

The prevalence of disseisin of common of pasture, including wood-pasture, is shown by the number of actions found throughout the rolls. ${ }^{27}$ In 1206 at Lincoln the jury precisely and at length defined the boundaries of disputed marshland, including an area accessible only by boat (nisi transitum cum batello suo), in a complicated case which produced an ambivalent outcome for the plaintiff. ${ }^{28}$ In 1221 at Worcester there is a glimpse of a perhaps long-running quarrel between neighbours - which may also have been the case between the Trowell litigants - when the defendant rather precipitately made a full confession to an accusation of disseisin of common of pasture. ${ }^{29}$ An interesting record of claims by different plaintiffs against the same defendant before the Berkshire eyre of 1248 seems to place a restriction on the use, as opposed to the area, of the pasture to which right of common was claimed. ${ }^{30}$ The plaintiffs enumerated the livestock they had habitually grazed 'everywhere in the aforesaid

\footnotetext{
${ }^{24}$ Bracton, De Legibus, iii. 166-78.

${ }^{25}$ C. Dyer, 'Conflict in the Landscape: The Enclosure Movement in England, 1220-1349', Landscape History, xxviii (2006), pp. 28-9.

${ }^{26}$ Dyer 'Conflict in the Landscape', p. 22.

${ }^{27}$ Birrell, 'Common Rights in the Medieval Forest', pp. 42-8.

${ }^{28}$ Earliest Lincolnshire Assize Rolls, ed. Stenton, no. 1411.

29 Rolls of the Justices in Eyre: Being the Rolls of Pleas and Assizes for Lincolnshire, 1218-19, and Worcestershire, 1221, ed. D.M. Stenton, Selden Society, liii (1934), no. 944.

${ }^{30}$ Roll and Writ File of the Berkshire Eyre of 1248, ed. Clanchy, no. 266.
} 
pasture' (ubique in predicta communa) until they had been disseised. Both actions were won. The situation at Trowell has a partial equivalent in a case before the Justiciar's special eyre of Surrey and Kent in $1259 .{ }^{31}$ Hugh del Molyn complained he had been prevented from pasturing 'all manner of his beasts' (cum omnimodis averiis suis) on half-an-acre throughout the year before it had been enclosed with a hedge and ditch. The jury found in his favour but with regard to one rood only. The Trowell mine case, then, was only one of a number of enrolled complaints of disseisin of common which frequently involved enclosure.

The area of Le Hek in the Trowell case appears to have been a defined piece of common wood-pasture. ${ }^{32}$ These were areas of less dense, often pollarded oak, woodland with sufficient space between the trees to allow for grazing. Located between agricultural land and dense woodland, these areas were often held as common and were sometimes, as here, enclosed as part of a larger grazing common. ${ }^{33}$ It was perhaps of considerable size since the plaintiffs were able to pasture draught animals of all kinds there throughout the year until Robert prevented them (in quo communicare solebant per totum annum cum omnimodis averiis suis quousque idem Robertus ipsos tenuit extra communam illam). It seems likely from its name, and from the fact that the plaintiffs and their animals could be kept off it, that it was an enclosed area. Possibly it was a hedged or fenced area within a larger common or one end of an elongated piece of land which had been partitioned off. ${ }^{34}$ It is not obvious from the entry in the roll when the wood-pasture had been enclosed. It is possible that it had been

\footnotetext{
${ }^{31}$ 1258-9 Special Eyre, ed. Hershey, no. 46.

${ }^{32}$ Birrell, 'Common Rights in the Medieval Forest', pp. 36-40. We would like to thank the first anonymous referee for bringing this important aspect to our attention.

${ }^{33}$ D. Hooke, 'Pre-Conquest Woodland: Its Distribution and Usage', Agricultural History Review, xxxvii (1989), pp. 116-17; O. Rackham, Ancient Woodland: Its History, Vegetation and Uses in England (Colvend, 2003), pp. 495-9, 502-3; O. Rackham, Woodlands (London, 2006), pp. 136, 149; A. Fleming, 'Working with Woodpasture' in S. Turner and B. Silvester, eds., Life in Medieval Landscapes: People and Places in the Middle Ages (Oxford, 2012), pp. 15-31.

${ }^{34}$ Revised Medieval Latin Word-list from British and Irish Sources, ed. R.E. Latham (Oxford, 1980), p. 223; A.H. Smith, English Place-name Elements, I: The Elements $A-\bar{I} W$, English Place Name Society, xxv (1956), p. 213; Hooke, 'Pre-Conquest Woodland', p. 123.
} 
fenced in recently because, according to Gilbert's claim, the plaintiffs had previously used it as customary pasture for their draught animals.

The case adds further nuance to our understanding of thirteenth-century enclosures and indicates that the novel disseisin cases presented before the courts may be a rich vein of information about these early features. Twelfth- and thirteenth-century enclosures, particularly of woodland, are generally associated with assarting and the drive for land clearance for new cultivation and more intensive land use. ${ }^{35}$ This was a period when the medieval English population was growing prodigiously and pressure on land resources was at its most intense. In many cases new, small-scale, assarts were incorporated into a settlement's common fields, as at Cossall, approximately 2.8 kilometres northwest of Trowell, where the twelfth- and early thirteenth-century assarts were incorporated into the open three-field structure. ${ }^{36}$ However, the Trowell case does not suggest that Robert sought to extend arable cultivation in this way. Instead, for Gilbert, it seems to have been the inaccessibility of the coal reserves, the 'other estovers' cited in the plea, that were his chief concern.

The enclosure, and Robert's motives for excluding his neighbours from this particular plot, appear therefore to have solely related to the mining operations there. This might have been a simple business decision. Robert may have come to the conclusion that the potential profits from selling coal outweighed the inconvenience to his neighbours of a slightly reduced area of wood-pasture. After all, the financial value of that pasture was negligible when compared to the potential cash revenues from coal sales in the burgeoning market economy of the mid-thirteenth century. Pasture, especially wood-pasture, tended to be a low-value resource (often described as 'waste'), and was used for rough grazing, pannage and, as seen above, fuel and timber. ${ }^{37}$ Between 1297 and 1326 inquisitions post mortem from

\footnotetext{
${ }^{35}$ Dyer, 'Conflict in the Landscape', p. 26.

${ }^{36}$ H.E. Hallam, ed., The agrarian history of England and Wales, II: 1042-1350 (Cambridge, 1988), pp. 327-8.

${ }^{37}$ Hallam, Agrarian History, pp. 198-202, 337-9; for the value of woodland in Wiltshire, see G. Clark, 'The Economics of Exhaustion, the Postan Thesis, and the Agricultural Revolution', Journal of Economic History, lii (1992), p. 68.
} 
Nottinghamshire suggest pastureland was worth, on average, just over $11 d$ per year if it was rented by the acre. ${ }^{38}$ Extracting and selling coal might have seemed like a lucrative alternative. In 1283, when William de Morteyn died, his manor at neighbouring Cossall was taken into the king's hands and valued. ${ }^{39}$ The resultant inquisition post mortem states that the 'herbage of the wood with the several [that is common] pasture is worth by the year $10 s^{\prime}$. Whilst the acreage of this wood-pasture is unknown and its value is reduced on account of it not being enclosed for William's personal use, the annual value of his coal mine was double that of his pasture, being valued at 20s. In making his decision, therefore, Robert might simply have done the maths.

Thus the enclosure at Trowell seems to have had had little to do with increasing the area under cultivation as other documentary sources, such as inquisitions post mortem, forest court pleas or patent rolls, might suggest. ${ }^{40}$ Rather the case indicates that this particular enclosure was the result of a speculative investment that sought remuneration from an embryonic coal-mining industry in the region. Thus the Trowell mine case, and the detail that it provides, highlights the potential that novel disseisin cases have for a multi-dimensional understanding of the uses of wood-pasture and early enclosure in the late twelfth and thirteenth centuries.

Much of the work on coal mining in Nottinghamshire has concentrated on the very full documentary evidence of the Willoughby family and its estate at Wollaton in the late sixteenth and early seventeenth centuries. ${ }^{41}$ In contrast, the Trowell case demonstrates much earlier evidence of commercial coal mining on the southern section of the Nottinghamshire

\footnotetext{
${ }^{38}$ Clark, 'Economics of Exhaustion', p. 69.

${ }^{39}$ Abstracts of the Inquisitiones Post Mortem and Other Inquisitions Relating to Nottinghamshire, 1279-1321, ed. J. Standish, Thoroton Society Record Series, iv (1914), p. 21.

${ }^{40}$ For inquisitions post mortem in general, see B.M.S. Campbell, English Seigniorial Agriculture, 1250-1450 (Cambridge, 2000), pp. 37-40; for other sources see, Dyer, 'Conflict in the Landscape', pp. 22-5.

${ }^{41}$ R.S. Smith, Early Coal-mining around Nottingham, 1500-1650 (Nottingham, 1989); J. Hatcher, The History of the British Coal Industry, I: Before 1700: Towards the Age of Coal (Oxford, 1993), pp. 165-70, 303, 337.
} 
coalfield where the coal lies close to the surface. Documents from later in the thirteenth century also reveal other mining operations close to Trowell. Cossall lies close to Trowell on the same exposed coal field. In 1283, the manor at Cossall included a coal mine valued at $20 \mathrm{~s}$ per annum. ${ }^{42}$ The Cossall mine complex, as with others in the region, included both iron ore and coal extraction and iron ore was being mined there around $1275 .{ }^{43}$ The Cossall mines continued to operate, on a significant scale, until the end of the fourteenth century. ${ }^{44}$ Other early mining operations were located in Smalley (Derbyshire, some ten kilometres from Trowell) and Selston (13 kilometres from Trowell). The coal mine at Smalley was in operation by 1283 when a dispute arose concerning its owner, the Abbot of Chester, who claimed that certain Derbyshire men had taken over the mine, beaten up the abbot's men who had been working there, and had stolen their tools and had prevented them from working. ${ }^{45}$ By 1306 a number of pits were also operational at Selston and these again, like those at Cossall contained both iron and coal pits. ${ }^{46}$ The evidence for mining at Selston was also the consequence of a dispute. The mine's landlord, William de Cantilupe, paid thirty-two cartloads of coal per annum to Simon of Grenhill and Lecia his wife in order to allow him to continue mining in Selston after destructive mining operations there had damaged three dwellings and gardens which belonged to the complainants in $1306 .{ }^{47}$ As this agreement settled an action for damage inflicted upon these properties in the past, a late thirteenth century date for the commencement of mining at Selston seems plausible. Whilst there is no evidence for mining in Selston in the later fourteenth century, extensive mining operations took place there from the mid-fifteenth century until the early sixteenth century when new

\footnotetext{
${ }^{42}$ Abstracts of the Inquisitiones Post Mortem, ed. Standish, p. 21.

${ }^{43}$ [University of Nottingham,] M[anuscripts and] S[pecial] C[ollections], Mi D 320/1. The document is undated but has been roughly dated palaeographically to $c .1275$.

${ }^{44}$ MSC, Mi D 340 (1312) and Mi D 343 (1316); Nottingham, N[ottinghamshire] A[rchives], CA 4400 (1348);

TNA, PRO, JUST 2/120, fo. 3d (1355); MSC, Mi D 377 (1362); TNA, PRO, E 326/1782 (1397).

${ }^{45}$ Calendar of Patent Rolls, 1281-1292, p. 65. For a murder that took place at the Smalley mine in 1398, see D.

Crook, 'Central England and the Revolt of the Earls, January 1400', Historical Research, lxiv (1991), p. 406.

${ }^{46}$ TNA, PRO, E 326/3216.

${ }^{47}$ TNA, PRO, E 326/3216.
} 
pits were sunk. ${ }^{48}$ Thus, whilst the 1258 date for the Trowell mine case remains the earliest date for mining operations in Nottinghamshire, this date is broadly in line with other evidence for coal mining during the thirteenth century in the area.

The Trowell mine case can tell us much, albeit occasionally hypothetically, about coal-mining operations in the region around this early date. First, the mining operation took place in a wood (quandam mineram carbonum...in predicto bosco), most likely in woodpasture. Much of the coal dug in the region was located in, or in close proximity to, land described as woodland. In many cases this is likely to have been wood-pasture. A number of places associated with later coal mining, such as at Strelley, Greasley and Kimberley, all within ten kilometres of Trowell, have been identified by the element Lēah in their place name, as areas containing wood-pasture. ${ }^{49}$ Furthermore, in 1312 Roger de Morteyn's mine at Cossall was located in his wood of Cossall Lount; miners at Selston were allowed to take wood from Selston for use as mining supports in the fifteenth century, again indicating a wooded area, and in the later fourteenth and fifteenth centuries mines were located in Eastwood and Underwood - their place names suggesting a wooded environment. ${ }^{50}$ The reason for the association of mining and woodland is probably two-fold. First, wood-pasture was, as in this case, often used for pastoral farming; therefore common fields or farm buildings rarely were an obstacle to prospecting for mineral deposits or to the mining operations themselves. The exception was Selston, mentioned above, where, as we have seen, coal mining did indeed blight properties in the area. In addition, the thin covering of trees in most areas of medieval wood-pasture allowed sufficient space for mining to take place without felling trees. Second, as seen in later mining leases, timber was used in propping

\footnotetext{
${ }^{48}$ NA, CA 1323, fo. 1 (1432); TNA, PRO, E 326/3217 (1457), E 326/81 (1490), and E 329/333 (1514).

${ }^{49}$ D. Hooke, 'Early Medieval Woodland and the Place-name Term lēah', in O.J. Padel and D. Parsons, eds., $A$ Commodity of Good Names: Essays in Honour of Margaret Gelling (Donington, 2008), p. 368.

${ }^{50}$ MSC, Mi D 340; TNA, PRO, E 326/1782, and E 315/32/211; NA, CA 1327, fo. 11; TNA, PRO, E 326/3217.
} 
excavations, for winding equipment and for draining the mine workings. ${ }^{51}$ Indeed, the use of the word scindere in the initial plea by Gilbert may point to timber being used in this way.

The Trowell case also indicates how some of the coal brought up to the surface was sold. The plea stated that 'Gilbert sold coal to certain people in that wood and the aforesaid Robert distrained them and did not allow them to carry away any of the aforesaid coal out of the wood (Gilbertus vendidit quibusdam carbonem in bosco illo. Et predictus Robertus ipsos devadiavit et non permisit eos aliquid asportare de carbone predicto extra boscum). This clearly demonstrates that pit-head sales were used in Trowell during the early days of the mine. The coal mined there was sold to local people who came to the pit head to buy coal and transport it away themselves presumably on packhorses or in carts, pulled by horses, or heavier wains, pulled by oxen. It is possible that some of these individuals were coalmongers who neither mined the coal nor owned the mines but rather acted, as in many other trades and industries, as middlemen and transported the coal to market. The transport of coal using wains can be inferred from the main unit of measurement of coal used in Nottingham having been the wain (plaustrum)-load, reflecting the normal carrying capacities of the local means of transport. The use of wains to transport coal from the pit can be seen explicitly in the 1540s, when the Nottinghamshire coroner investigated three carters who were killed, in separate incidents, whilst carrying coal. ${ }^{52}$ In the sixteenth century coal was collected from the pit head at Coleorton (Leicestershire) by local farmers using carts and wains. ${ }^{53}$ The Trowell case would therefore seem to confirm that pit-head sales were the principal method of marketing coal, both to local consumers and coalmongers, before the area's principal coal market in nearby Nottingham evolved to its fullest extent in the fourteenth century. Indeed, the alleged actions of Robert in not allowing customers to carry away any of the coal that they

\footnotetext{
${ }^{51}$ See, for example, TNA, PRO, C 146/7612 ,for the mine at Billborough (Nottinghamshire); R.F. Hartley, 'The Tudor Miners of Coleorton, Leicestershire', Bulletin of the Peak District Mines Historical Society, xii (1994), p. 92.

${ }^{52}$ See, for example, NA, CA 1322/II, fo. 5; Calendar of the Nottinghamshire Coroners' Inquests, 1485-1558, ed. R.F. Hunnisett, Throroton Society Record Series, xxv (1969), pp. 121, 132-3,159.

${ }^{53}$ Hatcher, History of the British Coal Industry, p. 461.
} 
had presumably just purchased from Gilbert at the pit head provides the earliest authoritative evidence of pit-head sales of coal that we know of in England.

The Trowell mine case also allows us to glimpse the scale of the operation and its management. The plea clearly describes the two men, Gilbert and Robert, both of whom were minor landlords, as having discovered the mine. Robert claimed in court, possibly as a defensive strategy in the face of Gilbert's stronger tenurial position, that they had made a deal to work the mine as an equal partnership (ita quod de communi assensu eorum carbonare providerunt ... quicumque alter eorum revocare vellet carbonem predictam uterque eorum cessaret de carbone amplius capiendo in bosco illo). Thus, in keeping with all medieval mining operations, this appears to have been a decidedly small-scale operation, probably involving a bell-pit type of mine (although not described as such [putei] in the plea), which were typical of both the period and the region. ${ }^{54}$ These were pits where a shaft was dug to reveal the coal seam and then coal was cut around the foot of the shaft in the shape of a bell until it became too dangerous to work, after which a new bell pit was dug nearby. In general, these mines were leased by landlords to small groups of miners. For example, in 1389 when the Trowell pits were more fully developed, the miners there paid a weekly rent based upon their output $-2 s 6 d$ for a " "pyke" of hard coal' and '12 $d$ for a "pyke" of culm' (lower grade coal or coal dust) to the landlord, Sir John Dabridgecourt. ${ }^{55}$ Individual coal pits were worked, often by just one or two miners, generally as a part-time enterprise, during the spring, summer and autumn months. ${ }^{56}$ No miners are mentioned in the 1258 case. However, it is tempting to speculate that Thomas le Rus, Henry son of Hugh and Robert of Stanley-who, with their animals, were kept out of the Le Hek enclosure by Robert - might have been the miners who worked the coal seam, whilst at the same time being pastoralists (alternatively they might have been customers or coalmongers). If they were in fact miners who were being prevented

\footnotetext{
${ }^{54}$ See, for example, MSC, Mi D 343; TNA, PRO, C 146/5081; NA, CA 1323, fo. 1; Hatcher, History of the British Coal Industry, pp. 188-9.

${ }^{55}$ MSC, Mi D 1145/1; for medieval mining leases, see Hatcher, History of the British Coal Industry, pp. 273-4.

${ }^{56}$ J. Birrell, 'Peasant Craftsmen in the Medieval Forest', Agricultural History Review, xvii (1969), pp. 101-2.
} 
from gaining entry to the workings_ - perhaps informally leasing the pit from Gilbert— then that would explain their connection to the case, and the relationship between the two pleas.

Coal mining was clearly an important opportunity for both men, as indicated by the fact that the dispute came to court and that Robert attempted to restrict entrance to the area to protect what he considered to be his assets and prevent Gilbert's continued mining there. This might be seen as an outcome of the 'commercialisation' of English society in the thirteenth century, whereby the mining of coal was encouraged by a developing commercial infrastructure and an increasing engagement with the market. ${ }^{57}$ The mid-thirteenth century, exactly when this case was heard, is generally considered to have been the period when commercialisation had reached its most developed form in the medieval era and was having an impact upon the lives and opportunities of most of the people of the British Isles. Much of the non-agricultural production in the countryside, and indeed much of the agricultural production as well, was devoted to supplying the market. By the beginning of the fourteenth century, both peasants and landlords had started to respond positively to rising demand and, in some cases, attempted to increase the productivity of their land. ${ }^{58}$ The appearance of the mine at Trowell (as well as at Cossall and Selston slightly later) in the documentary record coincides exactly with this commercial expansion witnessed in almost all aspects of the English economy. Were these two men exploiting the mineral resources beneath a fairly unproductive piece of wood-pasture in order to increase their manorial revenues through engagement with the market? Their digging of coal was not, as the plea clearly indicates, solely in order to supply their respective households with domestic fuel, because they were selling it at the pit head.

\footnotetext{
${ }^{57}$ R. Britnell, The Commercialisation of English Society, 1000-1500 (Manchester, 1996), pp. 102-27; J. Hatcher and M.Bailey, Modelling the Middle Ages: The History and Theory of England's Economic Development (Oxford, 2001), pp. 126-49.

${ }^{58}$ Britnell, Commercialisation of English Society, p. 123; B.M.S. Campbell, 'Land and People in the Middle Ages: 1066-1500', in R.A. Dodgshon and R.A. Butlin, eds., An Historical Geography of England and Wales (London, 1990), pp. 12-13, 22.
} 
The Trowell mine plea suggests that the mine had been discovered fairly recently (ipsi invenerunt quandam mineram carbonum) by the two men. Prospecting for coal and its exploitation for commercial purposes was a response to rising demand for coal for domestic heating and cooking, smithing and ironworking, lime burning and salt production in thirteenth- and early fourteenth-century England. ${ }^{59}$ Locally mined coal was certainly being used in Nottingham in the thirteenth century. In the year before the Trowell mine case, Queen Eleanor, whilst visiting Nottingham Castle, complained of the smoke coming from the coal being burned in the town, prompting the king to send her to stay at Tutbury (Thotebire) Castle instead. ${ }^{60}$ The contraction in woodland in England necessitated the increased uptake of coal, where it was available locally — as at Nottingham — for industrial purposes, especially in lime kilns. ${ }^{61}$ From the 1280 s onwards, complaints were regularly levelled at the brewers and limeburners of Southwark for the acrid pollution caused by their preference for burning coal, rather than brushwood or charcoal, in their kilns. ${ }^{62}$ In the years 1296-8 Lenton Priory (some five kilometres southeast of Trowell) bought seventy-two cartloads of coal for $13 s 8 d$ for use in its forges, and coal was also regularly recorded as being bought and sold in Nottingham from the 1330s onwards. ${ }^{63}$ Similar levels of demand probably stimulated the Bishop of Durham's coal mines on Tyneside. ${ }^{64}$ These are first specifically identified in the bishopric's archives from the $1270 \mathrm{~s}$, although earlier references to coal mining on Tyneside exist in the late twelfth century. ${ }^{65}$ This demand, combined with the relative low levels of investment required to open a new pit, may well have galvanised men such as Gilbert and Robert, in line with many of their contemporaries, to exploit the coal that lay beneath their feet. The

\footnotetext{
${ }^{59}$ Hatcher, History of the British Coal Industry, pp. 419-58.

${ }^{60}$ Annales monastici, ed. H.R. Luard, Rolls Series, xxxvi (5 vols., London, 1864-9), iii. 203-4.

${ }^{61}$ L.F. Salzman, Building in England down to 1540 (Oxford, 1952), p. 150.

${ }^{62}$ Hatcher, History of the British Coal Industry, p. 438; Calendar of Patent Rolls ,1281-1292, pp. 29, 296.

${ }^{63}$ Lenton Priory Estate Accounts, 1296 to 1298, ed. F.B. Stitt, Thoroton Society Record Series, xix (1959), pp. 10, 26; NA, CA 1262, fos. 1d-2, 7d.

${ }^{64}$ Hatcher, History of the British Coal Industry, pp. 72-4.

${ }^{65}$ Domesday Book, XXXV: Boldon Book: Northumberland and Durham, Supplementary Volume, ed. D. Austin (Chichester, 1982), pp. 70-71.
} 
importance of the mine to these men must have related to the revenues, or potential revenues, that it produced for them in pit-head sales.

The value of the enterprise might be gauged in the $40 \mathrm{~s}$ damages awarded to Gilbert after he won the case. This is a significant award worth about (very roughly) fifteen stones of wool or twelve quarters of wheat. If this was supposed to compensate Gilbert for his loss of revenue whilst the mine was out of operation during Robert's picketing, then it represents a significant output. By comparison, in 1283 the coal mine at Cossall was valued at 20s per annum, representing almost 10 per cent of the manor's yearly revenue. ${ }^{66}$ In Nottingham in the 1330s a wain-load of coal could be purchased for between 12 and $16 d$, which would suggest a lost output for Gilbert as a consequence of Robert's action of roughly forty wain-loads. ${ }^{67}$ There is no evidence to indicate the length of time that Gilbert was kept out of the mine, but these figures suggest something of the potential financial importance of this enterprise within the commercialising economy of thirteenth-century England.

Gilbert and Robert's enterprise prospered. The coal pits at Trowell developed into a considerable commercial operation. In 1389 the then lord of the manor, Sir John Dabridgecourt, leased the three parts of the coalmine which then lay 'in the fields of Trowell situated at Morebrech and Wodebrech' to Robert Bay of Cossall, William Garnam and Nicholas Batell of Trowell. ${ }^{68}$ These were local miners who sought a lease to exploit the minerals that lay beneath a landlord's estate. Indeed, Nicholas Batell was one of the constables responsible for the collection of the 1377 Poll Tax at Trowell. ${ }^{69}$ This suggests a man of some standing within the community but one who, as the lease makes clear, intended to work the coal himself with his partners. ${ }^{70}$ The mine at that time produced two different grades of coal ('hard coal' and less valuable 'culm') and possessed a degree of structural

\footnotetext{
${ }^{66}$ Abstracts of the Inquisitiones Post Mortem, p. 21.

${ }^{67} \mathrm{NA}, \mathrm{CA} 1262$, fos. $2,7 \mathrm{~d}$.

${ }^{68} \mathrm{MS}, \mathrm{C}$ Mi D 1145/1 and Mi 2/70/1.

${ }^{69}$ The Poll Taxes of 1377, 1379 and 1381. II: Lincolnshire-Westmorland, vol. 1, ed. C. Fenwick (Oxford, 2001) pp. xix-xx, vol. 2, p. 278.

${ }^{70}$ MSC, Mi D 1145/1.
} 
sophistication - the mine was equipped with 'watergates' (drainage channels) and 'heddriftes' (passages driven or excavated horizontally, rather than vertically, into the hillside to extract coal). ${ }^{71}$

The coal outcrop at Trowell was mined until the early fifteenth century. Around 1423-4, Nicholas of Strelley, presumably a descendant of the Robert of Strelley named in the 1258 Trowell case, gained control over the mines at Trowell by leasing them (and other lands and tenements) from his brother, the esquire Peter of Strelley, and other local landlords. ${ }^{72}$ The Strelley family developed considerable coal-mining interests on their manor of Strelley in the late sixteenth and early seventeenth centuries. ${ }^{73}$ So, regardless of the outcome of the 1258 case, Robert of Strelley's descendants ultimately got the mine back. The evidence for mining at Trowell disappears after 1424, although it is likely that Nicholas of Strelley's operation there continued during the term of the life-time lease. Nicholas died in 1430. After this date there is no further evidence of mining at Trowell until the early seventeenth century, when Trowell and Cossall came under the direct management of the Willoughby family. ${ }^{74}$

Less is known about the Brinsley family's later connection to the Nottinghamshire coal industry. However, the family may not have abandoned it entirely. In 1437, Nicholas Brinsley, parson of Eastwood church, and possibly a descendant of the thirteenth-century Gilbert, paid William Mylnhagh of Kimberley a salary of $8 s$ to 'search out' (perquerend') coal in an, ultimately successful, attempt to develop the mining operation in Kimberley (four kilometres north of Trowell). ${ }^{75}$ These mines at Kimberley were certainly operational at the Dissolution, when they were worth $£ 13$ annually. ${ }^{76}$

\footnotetext{
${ }^{71} \mathrm{MSC}$, Mi D 1145/1 and Mi 2/70/1.

72 MSC, Mi 2/72/4 and Mi 2/70/35.

${ }^{73}$ Hatcher, History of the British Coal Industry, pp. 167-8.

${ }^{74}$ Hatcher, History of the British Coal Industry, pp. 353, 356.

${ }^{75}$ NA, CA 1328, fo. 12.

${ }^{76}$ Wiliam Dugdale, Monasticon Anglicanum, enlarged by John Caley, Henry Ellis, and Bulkeley Bandinel (6 vols. in 8, London, 1817-30), vi. 14
} 
The industrialised, highly capitalised scale of the mining operations of the Willoughby family at Wollaton and the prodigious levels of output achieved by the mechanised coal extraction of the early twentieth century in Nottinghamshire had to start somewhere. The Trowell mine case- - a dispute between two men over a small-scale mining operation in the 1250s which barely scratched the surface of the Nottinghamshire coal field-represents one page from the start of that story.

The University of Nottingham

RICHARD GODDARD

The University of Nottingham

JANICE MUSSON

\section{TRANSCRIPTION}

TNA JUST $1 / 1187$ rot. $16 .^{1}$

http://aalt.law.uh.edu/AALT3/H3/Just1no1187/aJust1no1187fronts/IMG_0037.htm

Adhuc de Assis[is] et juratis capt[is] apud Nottingh ${ }^{\mathrm{a}} \mathrm{m}$ die M[er]cur[ii] $\mathrm{p}[\mathrm{ro}] \mathrm{x}[\mathrm{im}]^{\mathrm{a}}$ ante

Nativitatem b[eat]e Mar[ie] anno xlij ${ }^{\mathrm{o}}$ coram H. le Bigod [e]t G. de Preston'

TNA JUST 1/1187 rot. 17.

http://aalt.law.uh.edu/AALT3/H3/Just1no1187/aJust1no1187fronts/IMG_0040.htm

Notingh[am] Assis ${ }^{\mathrm{a}}$ ven[it] recogn[itura] si Rob[er]tus de Stredleye ini[us]te [e]tc[etera] disseis[ivit] Gilb[ertu]m de Brunnesleye de lib[er]o tenem[en]to suo in Trowell $p[o s] t \mathrm{p}[\mathrm{rim}]^{\mathrm{a} m}$ [e]tc[etera] et un[de] quer[tur] q[uo]d disseis[ivit] eum de duabus p[ar]tibus . xviij ${ }^{\text {to }}$. acr[arum] bosci cum $\mathrm{p}[\mathrm{er}] \operatorname{tin}[\mathrm{enciis}]$.

${ }^{1}$ Eadem assis $^{\mathrm{a}} \mathrm{p}[\mathrm{er}]$ eosd[e]m rec[ognitores] venit recogn[itura] si idem Rob[ertu]s ini[us]te [e]tc[etera] disseis[ivit] eunde[m] Gilb[ertu]m Thom[am] le Rus . Henr[icum] fil[ium] Hugon[is] [e]t Rob[ertu]m de Stanleye de co[m]muna pasture sue in Stradleye [e]t Trowell que $\mathrm{p}[\mathrm{er}]$ tinent ad lib[eru]m ten[ementum] suu[m] in Trowell $\mathrm{p}[\mathrm{os}] \mathrm{t} \mathrm{p}[\mathrm{rim}]^{\mathrm{a} m}$ [e]tc[etera] . Et un[de] queri[tur] q[uo]d disseis[ivit] eos de co[m]muna pasture sue in quodam loco qui vocat[ur] le Hek' in quo co[m]municare soleba[n]t p[er] totu[m] annu[m] cu[m] om[n]i[m]odis averiis suis quousq[ue] idem Rob[ertu]s ip[s]os tenuit ext $[\mathrm{r}]^{\mathrm{a}} \operatorname{co}[\mathrm{m}] \mathrm{munam}$ 
illam quo min[us] ibidem co[m]municare possunt sicut solebant . Et Rob[er]tus ven[it] [e]t nichil dicit $\mathrm{q}[\mathrm{u}]^{\mathrm{a}}$ re assi[s]e remaneant . nisi $\mathrm{t}[\mathrm{a}] \mathrm{m}[\mathrm{en}] \mathrm{q}[\mathrm{uo}] \mathrm{d}$ dicit quoad $\mathrm{p}[\mathrm{rim}]^{\mathrm{a}} \mathrm{m}$ ass[is]am quod $\operatorname{rev}[\mathrm{er}] \mathrm{a}$ ip[s]e [e]t $\mathrm{p}[\mathrm{re}] \mathrm{d}[\mathrm{ic}] \mathrm{t}[\mathrm{u}] \mathrm{s}$ Gilb[ertu]s tenent $\mathrm{p}[\mathrm{ro}]$ indiviso $\mathrm{p}[\mathrm{re}] \mathrm{d}[\mathrm{i}] \mathrm{c}[\mathrm{tu}] \mathrm{m}$ boscum ubi idem Gilb[ertu]s modo quer ${ }^{\mathrm{i}}[\mathrm{tur}]$ se disseisiri in quo ip[s]i inveneru[n]t qua $[\mathrm{n}]$ dam mineram carbo[n]u[m] ita $\mathrm{q}[\mathrm{uo}] \mathrm{d}$ de co[m]muni assensu eo[rum] carbonare $\mathrm{p}[\mathrm{ro}]$ videru[n]t in $\mathrm{p}[\mathrm{re}] \mathrm{d}[\mathrm{ic}]$ to bosco sub tali condit[i]one $\mathrm{q}[\mathrm{uo}] \mathrm{d} \mathrm{qu}[\mathrm{i}]$ cumq[ue] alt[er] eo[rum] revocare vellet carbon[em] $\mathrm{p}[\mathrm{re}] \mathrm{d}[\mathrm{ic}] \mathrm{tam}($ sic $)$ ut[er]q[ue] eo[rum] cessaret de carbon[e] ampl[ius] capiendo in bosco illo . Et q[uo]d ip[s]e p[er] co[n]vent[i]o[n]em illam no[n] p[er]misit ip[su]m carbon[em] ibide[m] cap[er]e [e]t n[u]llam aliam disseis[inam] ei inde fecit pon[it] se sup[er] ass[is]am . Et quoad s[e]c[un]dam ass[is] ${ }^{\mathrm{a} m}$ dicit $\mathrm{q}[\mathrm{uo}] \mathrm{d} \mathrm{p}[\mathrm{re}] \mathrm{d}[\mathrm{ic}] \mathrm{ti}$ Thom[as] [e]t alii no[n] possu[n]t disse[is]iri de co[m]muna pasture in Stradleye $\mathrm{p}$ [er]tin[ente] ad aliquod lib[eru]m ten[ementum] in Trowell quia dic[it] $\mathrm{q}[\mathrm{uo}] \mathrm{d} \mathrm{n}[\mathrm{u}] \mathrm{lla}$ co[m]muna pasture in Stradleye $\mathrm{p}[\mathrm{er}] \operatorname{tin}[\mathrm{et}] \mathrm{ad}$ aliquod lib[eru]m ten[ementum] in Trowell . Et similit[er] dic[it] $\mathrm{q}[\mathrm{uo}] \mathrm{d}$ $\mathrm{p}[\mathrm{re}] \mathrm{d}[\mathrm{ic}] \mathrm{ti}$ Thom[as $] \mathrm{e}[\mathrm{t}]$ alii $\mathrm{nu}[\mathrm{n}] \mathrm{cq}[\mathrm{u}]^{\mathrm{a}}[\mathrm{m}]$ fueru[n $] \mathrm{t}$ in seisina de $\mathrm{p}[\mathrm{re}] \mathrm{d}[\mathrm{ic}] \mathrm{ta}$ co[m]muna pasture in $\mathrm{p}[\mathrm{re}] \mathrm{d}[\mathrm{ic}] \mathrm{tis}$ villis ita $\mathrm{q}[\mathrm{uo}] \mathrm{d}$ potueru[n]t inde disseisiri ut $\mathrm{p}[\mathrm{er}] \mathrm{tin}[\mathrm{et}]$ ad lib[eru]m ten[ementum] ip[s]o[rum] in $\mathrm{p}[\mathrm{re}] \mathrm{d}[\mathrm{ic}]$ ta villa. Dicit etiam $\mathrm{q}[\mathrm{uo}] \mathrm{d} \mathrm{p}[\mathrm{re}] \mathrm{d}[\mathrm{ic}]$ ta placia in $\mathrm{q}[\mathrm{u}]^{\mathrm{a}}$ se $\mathrm{d}[\mathrm{icu}] \mathrm{nt}$ disseisiri solummodo est in Stredleye [e]t nulla $\mathrm{p}[\mathrm{ar}] \mathrm{s}$ eiusdem in Trowell . Et de $\mathrm{p}[\mathrm{re}] \mathrm{d}[\mathrm{ic}] \mathrm{tis}$ pon[it] se sup[er] ass[is]am .

Jur[atores] quoad $\mathrm{p}[\mathrm{rim}]^{\mathrm{a} m}$ ass[is]am $\mathrm{d}[\mathrm{ic}] \mathrm{u}[\mathrm{n}] \mathrm{t} \quad \mathrm{q}[\mathrm{uo}] \mathrm{d} \quad \mathrm{rev}[\mathrm{er}] \mathrm{a} \quad \mathrm{p}[\mathrm{re}] \mathrm{d}[\mathrm{i}] \mathrm{c}[\mathrm{tu}] \mathrm{s}$ Rob[ertu]s impedivit $\mathrm{p}[\mathrm{re}] \mathrm{d}[\mathrm{i}] \mathrm{c}[\mathrm{tu}] \mathrm{m}$ Gilb[ertu]m $\mathrm{q}[\mathrm{uo}] \mathrm{d}$ no[n] potuit scindere nec aliqua estoveria cap[er]e in $\mathrm{p}[\mathrm{re}] \mathrm{d}[\mathrm{i}] \mathrm{c}[\mathrm{t}]$ o bosco $\mathrm{p}[\mathrm{ro}] \mathrm{ut}$ cap[er]e consuevit . $\mathrm{D}[\mathrm{icu}] \mathrm{nt}$ etiam $\mathrm{q}[\mathrm{uo}] \mathrm{d}$ ip[s]i de co[m]muni assensu eo[rum] carbonare fec[er]unt in bosco suo $p[\mathrm{re}] \mathrm{d}[\mathrm{i}] \mathrm{c}[\mathrm{t}] \mathrm{o}$ absq[ue] aliqua condit[i]one int[er] eos $\mathrm{p}[$ ro]visa $\mathrm{v}[\mathrm{e}] 1 \mathrm{p}[\mathrm{re}]$ locuta ita $\mathrm{q}[\mathrm{uo}] \mathrm{d}$ idem Gilb[ertu]s vendidit quibusda[m] carbon[em] in bosco illo . [e]t p[re]d[i]c[tu]s Rob[ertu]s ip[s]os devadiavit [e]t $\mathrm{no}[\mathrm{n}] \mathrm{p}[\mathrm{er}]$ misit eos aliquid asportare de carbone $\mathrm{p}[\mathrm{re}] \mathrm{d}[\mathrm{ic}]$ to ext $[\mathrm{r}]^{\mathrm{a}}$ boscum $\mathrm{p}[\mathrm{re}] \mathrm{d}[\mathrm{i}] \mathrm{c}[\mathrm{tu}] \mathrm{m}$ un[de] $\mathrm{d}[\mathrm{icu}] \mathrm{nt} \quad \mathrm{p}[\mathrm{re}] \mathrm{cise} \quad \mathrm{q}[\mathrm{uo}] \mathrm{d} \quad \mathrm{p}[\mathrm{re}] \mathrm{d}[\mathrm{ic}] \mathrm{t}[\mathrm{u}] \mathrm{s}$ Rob[er]tus disseis[ivit] $\mathrm{p}[\mathrm{re}] \mathrm{d}[\mathrm{ic}] \mathrm{t}[\mathrm{u}] \mathrm{m}$ Gilb[ertu]m de $\mathrm{p}[\mathrm{re}] \mathrm{d}[\mathrm{i}] \mathrm{c}[\mathrm{t}] \mathrm{o}$ ten[emento] $\mathrm{q}[\mathrm{uo}] \mathrm{d}$ posuit in visu suo ini[us]te [e]tc[etera] sicut 
breve dicit . Et i[de]o cons[ideratum] est $\mathrm{q}[\mathrm{uo}] \mathrm{d} \mathrm{p}[\mathrm{re}] \mathrm{d}[\mathrm{ic}] \mathrm{t}[\mathrm{u}] \mathrm{s}$ Gilb[er]tus recup[er]et inde seis[in] ${ }^{\mathrm{a}} \mathrm{m}$ suam $\mathrm{p}[\mathrm{ro}]$ (sic) visum recogn[itorum] . Et Rob[ertu]s in ${ }^{2} \mathrm{~m}[$ isericord]ia.

Et quoad s[e]c[un]dam ass[is] ${ }^{a} \mathrm{~m}$ d[icu]nt q[uo]d p[re]d[i]c[tu]s Rob[er]tus disseisivit $\mathrm{p}[\mathrm{re}] \mathrm{d}[\mathrm{i}] \mathrm{c}[\mathrm{t}]$ os Gilb[ertu]m . Thom[am $][\mathrm{e}] \mathrm{t}$ alios de $\mathrm{p}[\mathrm{re}] \mathrm{d}[\mathrm{i}] \mathrm{c}[\mathrm{t}] \mathrm{a}$ co[m]muna pasture sue in $\mathrm{p}[\mathrm{re}] \mathrm{d}[\mathrm{ic}]$ tis vill[is] $\mathrm{p}[\mathrm{er}] \mathrm{tinente} \mathrm{ad} \operatorname{lib}[\mathrm{eru}] \mathrm{m}$ tenementu[m] ip[s]o[rum] in Trowell ini[us]te [e]tc[etera] sicut breve dicit et $\mathrm{i}[\mathrm{de}] \mathrm{o}$ cons[ideratum] est $\mathrm{q}[\mathrm{uo}] \mathrm{d} \mathrm{p}[\mathrm{re}] \mathrm{d}[\mathrm{i}] \mathrm{c}[\mathrm{t}] \mathrm{i}{ }^{3} \mathrm{Gilb}[\mathrm{ertu}] \mathrm{s}[\mathrm{e}] \mathrm{t}$ alii recup[er]ent inde seis[in] ${ }^{a} m$ suam $p$ [er] visum recogn[itorum] . Et Rob[er]tus in $\mathrm{m}[\mathrm{isericord}] \mathrm{ia}$. Post ven[it] $\mathrm{p}[\mathrm{re}] \mathrm{d}[\mathrm{i}] \mathrm{c}[\mathrm{tu}] \mathrm{s}$ Rob[ertu]s [e]t off[er]t d[omi]no ${ }^{4}$ Regi unam $\operatorname{marc}[\mathrm{am}] \mathrm{p}[\mathrm{ro}] \mathrm{h}$ [abe]nda jur[ata] xxiiij ${ }^{\text {or }}$ ad convincend[um] xij ${ }^{\mathrm{ci}[\mathrm{m}]}$. Et recipit[ur] p[er] $\mathrm{pl}[$ egios].

Dampn $^{\mathrm{a}}$. prioris assi[s]e . xl s[olidi] . m[ediete] . c[lericis $]$.

Dampn $^{\mathrm{a}} \mathrm{s}[\mathrm{e}] \mathrm{c}[\mathrm{un}] \mathrm{de}$. iiijor $\mathrm{s}[\mathrm{olidi}]$. $\mathrm{t}[\mathrm{ot}]$. c[lericis $]$.

${ }^{1}$ Marginal note of ' $t$ ', meaning uncertain.

${ }^{2}$ Marginal note of ' $\mathrm{m}$ [isericord]ia' struck through.

${ }^{3}$ Marginal note of ' $m[$ isericord]ia' struck through.

${ }^{4}$ Marginal note of 'j m[arca]' struck through.

TNA JUST $1 / 1187$ rot. $19 \mathrm{~d}$.

http://aalt.law.uh.edu/AALT3/H3/Just1no1187/bJust1no1187dorses/IMG_0107.htm

Adhuc de assisis et jur[atis] captis ap[u]d Suthwell die Martis $\mathrm{p}[\mathrm{ro}] \mathrm{x}[\mathrm{im}]^{\mathrm{a}}$ post Nativitatem be[ate] Marie virginis

http://aalt.law.uh.edu/AALT3/H3/Just1no1187/bJust1no1187dorses/IMG_0108.htm

Nottingh[am] Rob[ertu]s de Stredlegh qui tulit juratam . xxiiij . ad convincend[um] xij . v[er]sus Gilb[ertu]m de Brinesl' de comuna (sic) pastur[e] in Stredlegh [e]t Trowell scil[ice]t de quadam pastura que vocat[ur] le Hek . ven[it] [e]t ret[r] $]^{\mathrm{a} x i t}$ se . I[de]o Gilb[ertu]s inde sine die et ${ }^{1}$ Rob[ertu]s convi[n]c[atur] Gayol[e] [e]t pl[egii] sui de $\mathrm{p}[\mathrm{ro}] \mathrm{s}$ [equendo] in $\mathrm{m}[\mathrm{isericordi}] \mathrm{a}$. Quer[atur] nomi[n]a (sic) pl[egii] .

${ }^{1}$ Marginal note of 'm[isericord]ia' struck through. 


\section{TRANSLATION}

TNA JUST $1 / 1187$ rot. $16 .^{2}$

http://aalt.law.uh.edu/AALT3/H3/Just1no1187/aJust1no1187fronts/IMG_0037.htm

Still concerning the assizes and jury-pleas taken at Nottingham on the Wednesday next before the Nativity of the Blessed Mary in year 42 before H. Le Bigod and G. de Preston

TNA JUST 1/1187 rot. 17.

http://aalt.law.uh.edu/AALT3/H3/Just1no1187/aJust1no1187fronts/IMG_0040.htm

Nottingham An assize comes to recognize if Robert of Strelley unjustly etcetera disseised Gilbert of Brinsley of his free tenement in Trowell after the first etcetera. And whereof he (Gilbert) complains that he (Robert) disseised him of two parts of 18 acres of wood with appurtenances.

${ }^{1}$ The same assize through the same recognitors comes to recognize if the same Robert unjustly etcetera disseised the same Gilbert, Thomas le Rus, Henry son of Hugh and Robert of Stanley (Derbyshire) of their common of pasture in Strelley and Trowell which belongs to their free tenement in Trowell after the first etcetera. And whereof he (Gilbert) complains that he disseised them of their common of pasture in a certain place that is called Le Hek in which they were accustomed to have rights of common throughout the year with their draught animals of all kinds until the same Robert kept them outside that common (land), so that they were less able to have common there than they were accustomed to have. And Robert comes and says nothing (as to) why the assizes should stand over except however that he says, regarding the first assize, that in truth he and the aforesaid Gilbert held jointly the aforesaid wood, where the same Gilbert now complains to have been disseised, in which they found a certain coal mine so that, by their common assent, they undertook to mine the coal in the aforesaid wood on condition that whichever one of them should wish to withdraw from the aforesaid coal, the other of them would cease from further taking coal in that wood; and that he (Robert), through that agreement, has not allowed him to take coal there and no other disseisin has he caused him in respect thereof (and) he puts himself upon the assize. And as to the second assize, he says that the aforesaid Thomas and the others could not have been 
disseised of common of pasture in Strelley pertaining to any free tenement in Trowell, because he says that no common of pasture in Strelley pertains to any free tenement in Trowell. And similarly he says that the aforesaid Thomas and the others have never been in seisin of the aforesaid common of pasture in the aforesaid townships, so that they could (not) have been disseised in respect thereof when it does pertain to their free tenement in the aforesaid township. He says also that the aforesaid piece of ground in which they say they have been disseised is in Strelley alone and no part of the same (is) in Trowell. And concerning the aforesaid, he puts himself upon the assize.

The jurors, to the first assize, say that in truth the aforesaid Robert impeded the aforesaid Gilbert (so) that he could not fell trees nor take any estovers in the aforesaid wood as he was accustomed to take. They say also that, by their common assent, they arranged to mine coal in their aforesaid wood without any condition between them having been provided or agreed beforehand, so that the same Gilbert sold coal to certain people in that wood and the aforesaid Robert distrained them and did not allow them to carry away any of the aforesaid coal out of the wood aforesaid; whereof they say specifically that the aforesaid Robert disseised the aforesaid Gilbert of the aforesaid tenement that he put in their view unjustly etcetera just as the writ says. And therefore it is considered that the aforesaid Gilbert should recover his seisin thereof through the view of the recognitors. And Robert (is) ${ }^{2}$ in mercy.

And to the second assize, they say that the aforesaid Robert disseised the aforesaid Gilbert, Thomas and the others concerning their aforesaid common of pasture in the aforesaid townships, pertaining to their free tenement in Trowell, unjustly etcetera just as the writ says. And therefore it is considered that the aforesaid ${ }^{3}$ Gilbert and the others should recover their seisin thereof through the view of the recognitors, and Robert (is) in mercy. Afterwards the aforesaid Robert comes and offers to the Lord ${ }^{4}$ King one mark to have a jury of 24 to attaint the 12. And it is to be guaranteed by pledges.

Damages of the first assize: 40 s, half to the clerks.

Damages of the second: $4 \mathrm{~s}$, all to the clerks. 
${ }^{1}$ Marginal note of ' $t$ ', meaning uncertain.
${ }^{2}$ Marginal note of 'in mercy' struck through.
${ }^{3}$ Marginal note of 'in mercy' struck through.
${ }^{4}$ Marginal note of 'in mercy' struck through.

TNA JUST 1/1187 rot. 19d.

http://aalt.law.uh.edu/AALT3/H3/Just1no1187/bJust1no1187dorses/IMG_0107.htm

Still concerning the assizes and jury-pleas taken at Southwell on the Tuesday next after the

Nativity of the Blessed Virgin Mary

http://aalt.law.uh.edu/AALT3/H3/Just1no1187/bJust1no1187dorses/IMG_0108.htm

Nottingham Robert of Strelley who brought a jury of 24 to attaint 12 against Gilbert of Brinsley concerning common of pasture in Strelley and Trowell, namely concerning a certain pasture called 'Le Hek', has come and withdrawn himself. Therefore Gilbert (is) without day in respect thereof and ${ }^{1}$ Robert is condemned to gaol and his pledges for the prosecution (are) in mercy. Let him complain in the name of a pledge.

${ }^{1}$ Marginal note of 'in mercy' struck through.

\footnotetext{
${ }^{1}$ Citations to National Archives document JUST 1/1187 refer to the digital archive assembled by Robert C. Palmer and Elspeth K. Palmer, The Anglo-American Legal Tradition available at aalt.law.uh.edu/aalt.html, hereafter AALT.

${ }^{2}$ Citations to National Archives document JUST 1/1187 refer to the digital archive assembled by Robert C. Palmer and Elspeth K. Palmer, The Anglo-American Legal Tradition available at aalt.law.uh.edu/aalt.html, hereafter AALT.
} 